\title{
LATIHAN PSIKOFISIOLOGIKAL TAI CHI TERHADAP NYERI LUTUT PADA OSTEOARTRITIS
}

\section{Psychophysiological Training Of Tai Chi On Knee Pain In Osteoarthritis}

\author{
Gede Arya Bagus Arisudhana ${ }^{1}$, Ni Luh Resmiasih ${ }^{2}$ \\ ${ }^{1}$ Departemen Keperawatan Medikal Bedah, STIKES Bina Usada Bali, Badung, Indonesia \\ ${ }^{2}$ Program S1 Keperawatan, STIKES Bina Usada Bali, Badung, Indonesia \\ Korespondensi : aryabagus08@gmail.com
}

\begin{abstract}
ABSTRAK
Nyeri merupakan masalah keperawatan yang paling banyak terjadi pada penderita osteoarthritis (OA). Upaya menurunkan nyeri dapat dilakukan dengan melakukan latihan psikofisiologikal tai chi. Tujuan penelitian ini adalah untuk mengetahui pengaruh latihan psikofisiologikal tai chi terhadap nyeri lutut pada osteoartritis. Penelitian ini merupakan penelitian pre-eksperimen dengan pendekatan one group pre test post test design. Jumlah sampel dalam penelitian ini adalah 30 dengan metode sampling non-randomize. Analisa data menggunakan wilcoxon sign rank test. Alat ukur yang digunakan adalah numeric rating scale (NRS). Hasil penelitian menunjukkan rata-rata usia responden dalam penelitian ini adalah 65 tahun, dengan sebagian besar responden berjenis kelamin perempuan (70\%). Perbadingan nilai nyeri sebelum dan sesudah latihan psikofisiologikal tai chi menunjukkan rata-rata nyeri sebelum diberikan intervensi adalah 5,20, dan rata-rata nyeri setelah diberikan intervensi adalah 3,83. Hasil uji perbedaan skala nyeri sebelum dan setelah diberikan intervensi menggunakan wilcoxon sign rank test, diperoleh nilai $\mathrm{Z}_{\text {hitung }} 4,396$ dan nilai $\mathrm{p}=0,000(\alpha<0,05)$. Latihan tai chi bermanfaat dalam mengurangi nyeri dan sangat disarankan untuk populasi yang sesuai seperti lansia. Perlu dilakukan penelitian lebih banyak tentang efek tai chi sebagai intervensi dari perspektif keperawatan.
\end{abstract}

Kata kunci: nyeri, tai chi, osteoarthritis

\section{ABSTRACT}

Pain is a nursing problem that most occurs in people with osteoarthritis (OA). The efforts to reduce pain can be done by doing psychophysiological training of tai chi. The purpose of this study was to determine the effect of psychophysiological training of tai chi on knee pain in osteoarthritis. This research is a pre-experiment study with a one group pre test post test design approach. The number of samples in this study was 30 with a non-randomize sampling method. Data analysis using the Wilcoxon sign rank test. The measuring instrument used is a numeric rating scale (NRS). The results showed that the average age of respondents in this study was 65 years, with the majority of respondents being female (70\%). Comparison of pain scores before and after psychophysiological training of tai chi showed that the average pain before intervention was 5.20, and the average pain after intervention was 3.83. The test results of the difference in pain scale before and after the intervention were given using the wilcoxon sign rank test, obtained a $Z$ value count of 4.396 and a value of $p=0,000(\alpha<0.05)$. Tai chi exercises are useful in reducing pain and highly recommended for suitable populations such as the elderly. More research is needed about the effect of tai chi as an intervention from a nursing perspective.

Keywords: pain, tai chi, osteoarthritis 


\section{PENDAHULUAN}

Osteoartritis (OA) merupakan salah satu masalah kesehatan yang banyak terjadi pada orang dewasa dan lanjut usia. Onset OA dimulai pada usia paruh baya dan usia lebih dari 65 tahun mengalami degenerasi (White, Duncan, \& Baumle, 2013). World Health Organization (WHO) menyebutkan diperkirakan $9,6 \%$ pria dan $18 \%$ wanita di dunia yang berusia 60 tahun atau lebih akan memiliki gejala OA (World Health Organization, 2016). Wanita lebih bereisiko mengalami OA daripada laki-laki (White et al., 2013). Prevalensi OA akan terus meningkat seiring bertambahnya populasi, usia, dan faktor resiko seperti obesitas. OA mengakibatkan nyeri, kekakuan sendi dan kehilangan fungsi, serta disabilitas (Yan et al., 2013).

Dampak yang ditimbulkan OA membutuhkan tatalaksana yang komprehensif. Manajemen tatalaksana OA berfokus pada penanganan masalah nyeri yang dirasakan melalui edukasi pasien tentang penyakit yang di alami, mengembalikan fungsi, memperlambat perkembangan penyakit, dan mempertahankan kualitas hidup pasien (Ye, Cai, Zhong, Cai, \& Zheng, 2014). Sebuah meta-analisa dilakukan American College of Rheumatology dengan merekomendasikan penderita OA melakukan rehabilitasi berupa latihan kebugaran aerobik (J. Richmond et al., 2010). Penelitian lain menyebutkan bahwa intervensi psikofisiologikal, sejenis terapi alternatif dapat mengatasi masalah nyeri pada pasien OA dengan meningkatkan kadar endorfin dan enkefalin (Ye et al.,2014).

Tai chi, salah satu jenis terapi psikofisiologikal (Ariayi, Sarchahi, \& Javaheri, 2017). Tai chi merupakan sebuah intervensi yang mengkombinasikan teknik nafas diafragma dan relaksasi dengan berbagai gerakan yang dilakukan secara perlahan dari gerakan satu ke gerakan lainnya (Ye et al., 2014). Tai chi dilaporkan dapat menurunkan nyeri pada sendi (Tsai et al., 2009). Sebuah penelitian melaporkan, tai chi dapat dimodifikasi dan disesuaikan dengan kondisi lansia. Hal ini dilakukan untuk memungkinkan lansia dengan fisik yang lemah dapat melakukan latihan dalam posisi duduk aupun berdiri, serta dapat melakukan diruangan yang kecil dan kapan saja secara individu maupun berkelompok (Tsai et al., 2009).

Lansia dengan masalah OA akan mengalami penurunan fungsi yang nyata salah satunya gangguan nyeri pada persendian lutut yang mengalami OA. Nyeri yang dialami dapat menurunkan produktivitas lansia sehingga tidak dapat beraktivitas dengan nyaman. Dibutuhkan sebuah upaya mengatasi masalah nyeri melalui perawatan dalam bentuk latihan. Untuk itu perlu dilakukan penelitian tentang pengaruh latihan psikofisikologikal tai chi terhadap nyeri lutut pada osteoartritis.

\section{TUJUAN PENELITIAN}

Penelitian ini bertujuan untuk mengetahui pengaruh latihan psikofisiologikal tai chi terhadap nyeri lutut pada osteoartritis.

\section{METODE PENELITIAN}

Desain

Penelitian ini merupakan jenis preeksperimen dengan pendekatan one group pre test post test design.

\section{Populasi dan Sampel}

Populasi terjangkau dalam penelitian ini adalah seluruh lansia dengan OA lutut. Sampel dalam penelitian ini ditentukan berdasarkan metode non-randomize. Sampel di rekrut dari sebuah rukun warga (RW). Jumlah sampel dalam penelitian ini adalah 30 . Kriteria inklusi dalam penelitian ini adalah berusia 60 tahun keatas, melaporkan nyeri pada sendi lutut karena OA, nyeri osteoartritis lebih dari 3 bulan, skala nyeri 5 keatas, tidak mengalami sindroma depresi, tidak pernah mengikuti program latihan fisik sebelumnya.

Kriteria eksklusi dalam penelitian ini adalah mengalami fraktur ekstremitas 6 bulan terakhir, mengalami gangguan pendengaran yang parah, mengalami parkinson, mengalami diabetes neuropati, nyeri karena kanker, pasien riwayat operasi penggangian hip, memiliki riwayat vertigo, dan mengkonsumsi obat penghilang nyeri.

\section{Tempat dan Waktu Penelitian}

Penelitian ini dilaksanakan selama 6 minggu di Desa Depeha Kecamatan Kubutambahan Kabupaten Buleleng.

\section{Intervensi}

Responden yang telah memenuhi kriteria penelitian akan mendapat sebuah latihan psikofisikologikal berupa senam tai chi. Senam tai chi dilaksanakan disebuah ruang pertemuan desa setiap 2 kali dalam seminggu selama 6 minggu. Setiap sesi 
latihan dilaksanakan dengan durasi 20-40 menit.

Latihan dilakukan pada pagi hari dan dibantu oleh seorang instruktur yang telah bersertifikat dengan pengalaman lebih dari 4 tahun memimpin peserta senam tai chi. Instruktur meningkatkan waktu latihan dari 2040 menit secara bertahap saat peserta latihan telah memperoleh kekuatan fisik. Instruktur memulai dengan gerakan tahap pertama (gambar 1a) dan menambahkan gerakan tahap berikutnya (gambar 1b, 1c, 1d, 1e).

Gambar 1

Langkah-Langkah Senam Tai Chi

A
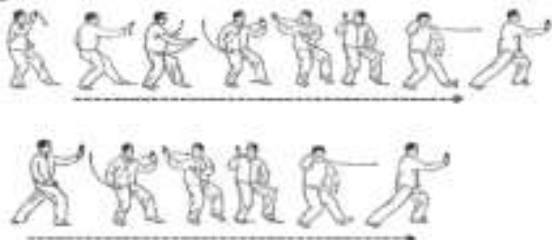

B

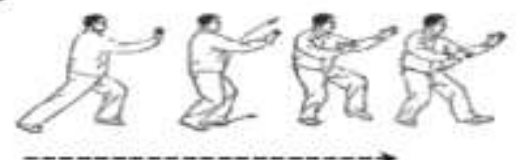

C

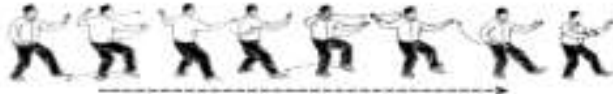

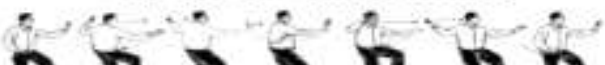

$n \cap n \times n n$

D
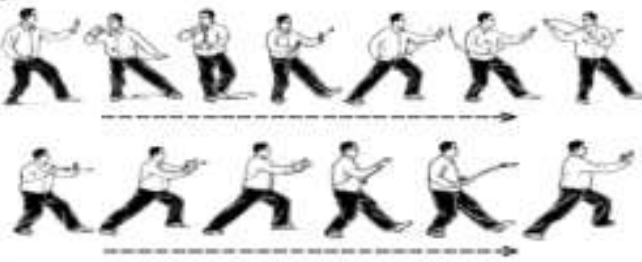

E
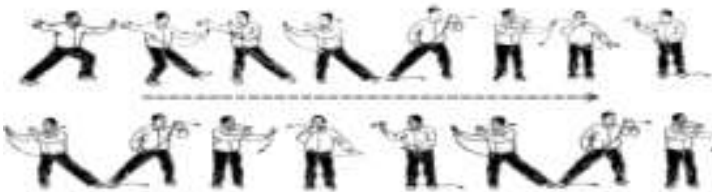

Sumber: Lai, Wang, Lee, Hou, \& Wang, (2017)

\section{Instrumen dan Prosedur Pengukuran}

Instrumen yang digunakan dalam penelitian ini adalah Numeric Rating Scale (NRS) untuk mengukur tingkat nyeri yang dirasakan responden. Nyeri akan diukur sebelum dan sesudah intervensi diberikan, responden ditunjukkan angka dari 0 sampai 10 . Responden diminta untuk melingkari salah satu dari 0 sampai dengan 10 sebagai bentuk interpretasi rasa nyeri yang dirasakan. Angka 0 menunjukkan tidak ada nyeri yang dirasakan dan angka 10 menyatakan nyeri yang sangat hebat.

Skala NRS memiliki validitas construct yang baik dan memiliki reliabilias yang stabil (Summers, 2001). NRS memiliki statibilitas koefisien sebesar 0,63 dan validitas koefesien sebesar 0,74 (Jensen \& McFarland, 1993). NRS memiliki tingkat akurasi yang baik dalam pengukuran nyeri pada lansia, nilai akurasi mencapai $0,76(76 \%)$ dengan nilai sensitifitas $68 \%$ dan spesifitas $78 \%$ (Krebs, Carey, \& Weinberger, 2007).

Gambar 2

Pain Numeric Rating Scale

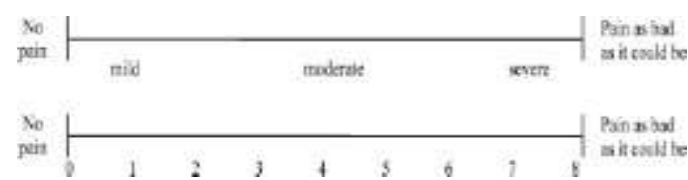

Sumber: Haefeli \& Elfering, (2006)

\section{Analisa Data}

Analisa univariat dilakukan pada data karakteristik responden. Analisa bivariat dilakukan pada variabel nyeri menggunakan uji non-parametrik wilcoxon signed rank.

\section{HASIL PENELITIAN}

Hasil akan disajikan dalam tabel berikut ini:

Tabel 1

Karakteristik Responden $(\mathrm{n}=30)$

\begin{tabular}{|c|c|c|}
\hline Variabel & Mean \pm SD & $\begin{array}{c}\text { Frekuensi } \\
(\%)\end{array}$ \\
\hline Usia & $65 \pm 2.850$ & \\
\hline \multicolumn{3}{|l|}{ Jenis Kelamin } \\
\hline 1. Laki-laki & & 30 \\
\hline 2. Perempuan & & 70 \\
\hline
\end{tabular}

responden dalam penelitian ini adalah 65 tahun, dengan sebagian besar responden berjenis kelamin perempuan $(70 \%)$.

Tabel 2

Nyeri Osteoartritis $(\mathrm{n}=30)$

\begin{tabular}{|c|c|c|c|}
\hline Variabel & Mean \pm SD & Z & $\begin{array}{l}\text { Sig.2- } \\
\text { tailed }\end{array}$ \\
\hline Pretest & $5,20 \pm 0,407$ & & \\
\hline $\begin{array}{l}\text { Posttest } \\
\text { Pretest- }\end{array}$ & $3,83 \pm 0,874$ & & \\
\hline Posttest & $\underline{1,67 \pm 0,959}$ & $\underline{4,396}$ & $\underline{0,001}$ \\
\hline
\end{tabular}


Tabel 2 menyajikan rata-rata nyeri sebelum diberikan intervensi adalah 5,20, dan rata-rata nyeri setelah diberikan intervensi adalah 3,83 . Hasil uji perbedaan skala nyeri sebelum dan setelah diberikan intervensi menggunakan wilcoxon sign rank test, diperoleh nilai $Z_{\text {hitung }} 4,396$ dan nilai $p=0,000$ $(\alpha<0,05)$.

\section{PEMBAHASAN}

OA pada lutut merupakan salah satu penyebab utama disabilitas pada lansia (Ma, Chan, \& Carruthers, 2014). Jenis kelamin dan usia dijelaskan merupakan faktor prediktor terjadinya OA. Responden dalam penelitian ini sebagaian besar memiliki jenis kelamin perempuan. Hal ini sesuai dengan teori yang dikemukakan oleh White et al., (2013) yang menjelaskan bahwa OA lebih banyak terjadi pada wanita (White et al., 2013). Cho et al., mengidentifikasi jenis kelamin wanita menjadi faktor predisposisi utama OA pada lutut dan memiliki manifestasi klinis yang lebih buruk dibandingkan dengan laki-laki (Cho, Chang, Yoo, Kim, \& Kim, 2010). Perbedaan hormon antara perempuan dan laki-laki dapat menjadi penyebab utama berkembangnya OA., terutama pada wanita postmenopause yang dikaitkan dengan penurunan estrogen (Hame \& Alexander, 2013). Sejalan dengan Hame \& Alexander, penelitian yang dilakukan Richmond et al., mengidentifikasi implikasi potensial yang terjadi reseptor estrogen pada kartilage persendian (Richmond et al., 2000).

Karakteristik responden yang dapat menjadi faktor predisposisi terjadinya OA adalah usia. Usia responden pada penelitian ini memiliki rata-rata usia 65 tahun. Usia yang semakin bertambah mempengaruhi kemampuan sel dan jaringan dalam mempertahankan homoeostasis terutama saat stress (Anderson \& Loeser, 2010). Proses penuaan dan perubahan patologis pada sendi OA pada tingkat molekuler terjadi akibat perubahan intrinsik dalam struktur protein matriks ekstraseluler seperti kolagen dan proteoglikan. Pengerasan pada jaringan kolagen atau peningkatan glikasi dapat menstimulus terjadin glikasi dapat menstimulus terjadinya gangguan fungsi kartilago dan fungsional sendi (Verzijl et al., 2002). Penuaan memiliki peranan dalam peningkatan terjadinya apoptosis dan regenerasi sel.
Pada penelitian ini diketahui nilai nyeri sebelum melakukan latihan tai chi memiliki rata-rata 5,20. Nyeri yang dirasakan responden sebelum melakukan latihan tai chi pada OA lutut sebagian besar memiliki karakteristik nyeri sedang yang intermiten. Penelitian yang dilakukan Hawker et al., (2008) menjelaskan bahwa individu dengan OA lutut dan hip memiliki karakteristik nyeri yang intermeten dan intens (Neologi, 2013). Rasa sakit yang intermiten dan intens dirasakan penderita OA memiliki efek negatif pada suasana hati, menyebabkan gangguan tidur, dan mengakibatkan tidak dapat berpartisipasi dalam kegiatan sosial (Neologi, 2013).

Upaya dalam mengurangi nyeri responden dalam penelitian ini dilatih utuk melakukan latihan psikofisiologikal berupa tai chi. Setelah melakukan latihan tai chi selama 45 menit setiap 2 kali seminggu dalam 6 minggu, nyeri dirasakan semakin menurun oleh responden dibandingkan dengan sebelum rutin melakukan latihan tai chi. Hal ini sejalan dengan penelitian yang dilakukan oleh Shen et al., (2008) yang menunjukan perubahan nyeri yang dirasakan semakin berkurang setelah melakukan latihan tai chi setiap minggu 2 kali selama 6 minggu. Rata-rata skala nyeri setelah melakukan tai chi menurun menjadi 3,83. Dengan nilai rata-rata nyeri selisih antara pretest dan post-test adalah 1,67. (R. S. Richmond et al., 2000)

Tai chi merupakan salah satu latihan yang direkomendasikan dilakukan pada pasien OA pada lutut (J. Richmond et al., 2010). Nyeri yang dirasakan pada OA lutut dapat dikurangi dengan melakukan modifikasi pengobatan melalui latihan tanpa melihat stadium penyakit atau tingkat keparahan gejala OA (Fransen et al., 2015). Pada penelitian ini tai chi dilakasanakan selama 6 minggu. Secara teori, tai chi akan lebih efekif jika dilakukan dalam jangka panjang, namun beberapa penelitian menemukan efek positif dalam menghilangkan nyeri pada OA setelah durasi latihan 6-12 minggu (Brismée et al., 2007). Tai chi merupakan latihan yang menggabungkan teknik pernafasan diafragma dan relaksasi dengan berbagai gaya gerakan secara perlahan dan lembut, dari satu gerakan ke gerakan lainnya dengan gerakan melingkar (Ye et al., 2014). Chen \& Snyder (1999) menjelaskan, tai chi berfokus pada kombinasi dari imajinasi dan kenyataan, ketenangan dan tindakan, serta 
mencari ketenteraman dalam setiap gerakan (Ye et al., 2014). Tai chi yang dilakukan dan dipraktikkan oleh orang dewasa dengan OA mampu memberikan motivasi dan meningkatkan gaya hidup sehat (Chang, Chen, Lee, Lin, \& Lai, 2016). Selain itu, kekuatan otot ekstremitas bawah serta keseimbangan dan kemampuan koordinasi pasien dengan OA lutut dapat ditingkatkan melalui latihan tai chi (Wang et al., 2009).

\section{KESIMPULAN}

Implikasi

Secara umum, latihan tai chi bermanfaat dalam meningkatkan keseimbangan, mengurangi nyeri, dan mengurangi kekakuan serta sangat disarankan untuk populasi yang sesuai seperti lansia. Akan lebih bermanfaat bagi perawat untuk mempelajari tai chi dan kemudian dilaksanakan dalam praktik klinis sebagai sebuah intervensi keperawatan. Penelitian lebih lanjut guna mengeksplorasi variabel yang terkait dengan pasien seperti fisiologis, sikap, dan keyakinan serta variabel lainnya seperti demografi, preferensi modalitas pengobatan pada efektivitas tai chi. Selain itu, perlu dilakukan penelitian lebih banyak tentang efek tai chi sebagai intervensi dari perspektif keperawatan.

\section{Keterbatasan}

Tai chi merupakan sebuah terapi komplementer yang terus dikembangkan di Indonesia. Banyak penelitian telah dilakukan tentang manfaat tai chi dalam keperawatan, namun tidak semua orang dapat merasakan manfaat dari tai chi. Terdapat beberapa keterbatasan tai chi, khususnya pada gangguan OA. Instruktur latihan harus lebih menyadari keterbatasan dan melakukan penilaian awal pada teloransi orang dewasa dan/tau lansia dalam melakukan latihan. Selain itu, seorang pemula yang melakukan tai chi harus dievaluasi secara periodik pada kemajuan dan kepatuhan program, seperti respons kognitif, kekuatan otot, keseimbangan, dan fleksibilitas.

\section{DAFTAR PUSTAKA}

Anderson, A. S., \& Loeser, R. F. (2010). Why is OA an age-related disease. Best Pract Res Clin Rheumatol, 24(1), 1-18. https://doi.org/10.1016/j.berh.2009.08.006 .Why
Ariayi, E., Sarchahi, A., \& Javaheri, S. A. A. H. (2017). Comparative study of the effect of Tai Chi and isometric exercises on the severity of pain and balance in patients with knee osteoarthritis. Journal of Kerman University of Medical Sciences, 24(4), 268-277.

Brismée, J. M., Paige, R. L., Chyu, M. C., Boatright, J. D., Hagar, J. M., McCaleb, J. A., ... Shen, C. L. (2007). Group and home-based tai chi in elderly subjects with knee osteoarthritis: A randomized controlled trial. Clinical Rehabilitation, 21(2), 99-111. https://doi.org/10.1177/026921550607050 5

Chang, W.-D., Chen, S., Lee, C.-L., Lin, H.-Y., \& Lai, P.-T. (2016). The Effects of Tai Chi Chuan on Improving Mind-Body Health for Knee Osteoarthritis Patients: A Systematic Review and Meta-Analysis. Evidence-Based Complementary and Alternative Medicine, 2016. https://doi.org/10.1155/2016/1813979

Chen, K.-M., \& Snyder, M. (1999). Tai Chi / Movement Therapy as a Nursing Intervention. Journal of Holistic Nursing, 17(3), 267-279.

Cho, H. J., Chang, C. B., Yoo, J. H., Kim, S. J., \& Kim, T. K. (2010). Gender differences in the correlation between symptom and radiographic severity in patients with knee osteoarthritis. Clinical Orthopaedics and Related Research, 468(7), 1749-1758. https://doi.org/10.1007/s11999-010-1282$\mathrm{Z}$

Fransen, M., McConnell, S., Harmer, A. R., Esch, M. Van der, Simic, M., \& Bennell, K. L. (2015). Exercise for osteoarthritis of the knee. The Cochrane Library, (1), 1104. https://doi.org/10.1002/14651858.CD004 366.pub6.www.cochranelibrary.com

Haefeli, M., \& Elfering, A. (2006). Pain assessment. European Spine Journal, 15, S17-24. https://doi.org/10.1007/s00586005-1044-x

Hame, S. L., \& Alexander, R. A. (2013). Knee osteoarthritis in women. Current Reviews in Musculoskeletal Medicine, 6(2), 182187. https://doi.org/10.1007/s12178-0139164-0

Hawker, G. A., Stewart, L., French, M. R., Cibere, J., Jordan, J. M., March, L., ... 
Gooberman-Hill, R. (2008). Understanding the pain experience in hip and knee osteoarthritis - an OARSI/OMERACT initiative. Osteoarthritis and Cartilage, 16(4), 415422.

https://doi.org/10.1016/j.joca.2007.12.017 Jensen, M. P., \& McFarland, C. A. (1993). Increasing the reliability and validity of pain intensity measurement in chronic pain patients. Pain, 55(2), 195-203. https://doi.org/10.1016/03043959(93)90148-I

Krebs, E. E., Carey, T. S., \& Weinberger, M. (2007). Accuracy of the pain numeric rating scale as a screening test in primary care. Journal of General Internal Medicine, 22(10), 1453-1458. https://doi.org/10.1007/s11606-007-03212

Lai, Z., Wang, X., Lee, S., Hou, X., \& Wang, L. (2017). Effects of whole body vibration exercise on neuromuscular function for individuals with knee osteoarthritis: Study protocol for a randomized controlled trial. Trials, 18(1), 1-9. https://doi.org/10.1186/s13063-017-21706

Ma, V. Y., Chan, L., \& Carruthers, K. J. (2014). The Incidence, Prevalence, Costs and Impact on Disability of Common Conditions Requiring Rehabilitation in the US: Stroke, Spinal Cord Injury, Traumatic Brain Injury, Multiple Sclerosis, Osteoarthritis, Rheumatoid Arthritis, Limb Loss, and Back Pain. Arch Phys Med Rehabil, 95(5), 986-995. https://doi.org/10.1016/j.apmr.2013.10.03 2.The

Neologi, T. (2013). The Epidemiology and Impact of Paing in Osteoarthritis. Osteoarthritis Cartilage, 21(9), 11451153.

https://doi.org/10.1016/j.joca.2013.03.018 .The

Richmond, J., Hunter, D., Irrgang, J., Jones, M. H., Snyder-Mackler, L., Durme, D. Van, ... McGowan, R. (2010). American Academy of Orthopaedic Surgeons Clinical Practice Guideline on: The Treatment of Osteoarthritis (OA) of the Knee. The Journal of Bone and Joint Surgery, 92, 990-993. https://doi.org/10.2106/JBJS.938ebo
Richmond, R. S., Carlson, C. S., Register, T. C., Shanker, G., \& Loeser, R. F. (2000). Functional estrogen receptors in adult articular cartilage: Estrogen replacement therapy increases chondrocyte synthesis of proteoglycans and insulin-like growth factor binding protein 2. Arthritis and Rheumatism, 43(9), 2081-2090. https://doi.org/10.1002/15290131(200009)43:9<2081::AIDANR20>3.0.CO;2-I

Shen, C.-L., James, C. R., Chyu, M.-C., Bixby, W. R., Brismée, J.-M., Zumwalt, M. A., \& Poklikuha, G. (2008). Effects of Tai Chi on Gait Kinematics, Physical Function, and Pain in Elderly with Knee Osteoarthritis - A Pilot Study. The American Journal of Chinese Medicine, $36(02)$, 219-232. https://doi.org/10.1142/S0192415X08005 734

Summers, S. (2001). Evidence-based practice part 2: Reliability and validity of selected acute pain instruments. Journal of Perianesthesia Nursing, 16(1), 35-40. https://doi.org/10.1053/jpan.2001.20657

Tsai, P.-F., Beck, C., Chang, J. Y., Hagen, J., Yong-Fang, K., Roberson, P. K., ... Anand, K. J. S. (2009). The Effect of Tai Chi on Knee Osteoarthritis Pain in Cognitively Impaired Elders: Pilot Study. Geriatric Nursing, 30(2), 132-139. https://doi.org/10.1016/j.gerinurse.2007.1 1.002.The

Verzijl, N., DeGroot, J., Ben Zaken, C., BraunBenjamin, O., Maroudas, A., Bank, R. A., ... TeKoppele, J. M. (2002). Crosslinking by Advanced Glycation End Products Increases the Stiffness of the Collagen Network in Human Articular Cartilage. Arthritis and Rheumatism, 46(1), 114123. https://doi.org/10.1002/art.10025 Wang, C., Schmid, C. H., Hibberd, P. L., Kalish, R., Roubenoff, R., Rones, R., \& McAlindon, T. (2009). Tai Chi is Effective in Treating Knee Osteoarthritis: A Randomized Controlled Trial. Arthritis Rheumathoid, 61(11), 1545-1553. https://doi.org/10.1002/art.24832.Tai

White, L., Duncan, G., \& Baumle, W. (2013). Medical-Surgical Nursing An Integrated Approach (3rd ed.). New York: Delmar, Cengage Learning. 
Gede Arya Bagus Arisudhana, dkk: Latihan Psikofisiologikal Tai Chi Terhadap Nyeri Lutut Pada Osteoartritis

World Health Organization. (2016). Chronic rheumatic conditions. Retrieved November 3, 2018, from http://www.who.int/chp/topics/rheumatic/ en/

Yan, J. H., Gu, W. J., Sun, J., Zhang, W. X., Li, B. W., \& Pan, L. (2013). Efficacy of Tai Chi on Pain, Stiffness and Function in Patients with Osteoarthritis: A MetaAnalysis. PLoS ONE, 8(4), 1-9. https://doi.org/10.1371/journal.pone.0061 672

Ye, J., Cai, S., Zhong, W., Cai, S., \& Zheng, Q. (2014). Effects of Tai Chi for Patients with Knee Osteoarthritis: A Systematic Review. Journal of Physical Therapy Science, 26(7), 1133-1137. https://doi.org/10.1589/jpts.26.1133 